\title{
Sacred Space in Uyghur Buddhism
}

\author{
Jens Wilkens
}

\section{Introduction $^{1}$}

Buddhism became the major cultural driving force among the Uyghurs after it began to spread in earnest around the turn of the first millennium $\mathrm{CE}^{2}{ }^{2}$ It affected all arenas of cultural expression, such as architecture, visual arts, literature, poetry, and so on. Sacred space in Uyghur Buddhism is a topic which has not been researched in a systematic fashion so far, although some important points have been touched upon in previous research. ${ }^{3}$ When dealing with this issue, several key aspects are to be examined without reference to the complex discussion concerning the concept of 'the holy' or 'the sacred' in Religious Studies. A highly important issue connected with the topic is certainly pilgrimage, but as Simone-Christiane Raschmann's article "Pilgrims in Old Uyghur Inscriptions: A Glimpse behind their Records" (see Chapter 8 in this volume) is dealing with it, I refrain from discussing this most significant aspect of sacred space viewed from the angle of religious practice. While art historical and archaeological questions immediately come to mind, I will confine this investigation to a perusal of Old Uyghur texts, due to a lack of sufficient expertise in the aforementioned domains. A thorough investigation of the issue would be best accomplished by a team of specialists from those different fields. A combination of archaeological methods and philological expertise, for instance, has led Takao Moriyasu to discover the 'Manichaean layer' beneath a 'Buddhist

1 I would like to thank Yukiyo Kasai and Kirill Solonin for their remarks on my paper. All translations from primary sources are my own. The references are always to the Old Uyghur original in the text editions. A subscript number 2 in a translation denotes a hendiadys.

2 On Uyghur Buddhism, especially in the West Uyghur Kingdom (second half of 9th c. to 13th c.), see Jens Wilkens, "Buddhism in the West Uyghur Kingdom and Beyond," in Transfer of Buddhism Across Central Asian Networks (7th to 13th Centuries), ed. Carmen Meinert (Leiden, Boston: Brill, 2016), 191-249; Jens Wilkens, "Der Buddhismus bei den türkischen Völkern in Zentralasien," in Der Buddhismus II: Theravāda-Buddhismus und Tibetischer Buddhismus, ed. Manfred Hutter (Stuttgart: Kohlhammer, 2016), 469-49o; and Peter Zieme, "The West Uigur Kingdom: Views from Inside," Horizons 5.1 (2014): 1-29.

3 For example, the concept of the two orders - a spatial model of Buddhist governance which distinguishes between an inner (i.e. religious) and an outer (i.e. political) sphere. See Zieme, "The West Uigur Kingdom," 6-10. 
layer' in the well-known cave temples of Bezeklik near Turfan. ${ }^{4}$ This state of affairs is described metaphorically by Kim Knott as an example of 'place as palimpsest. ${ }^{5}$

A further line of enquiry would be whether the caves commissioned or executed by Uyghurs in the Turfan area, at Dunhuang (敦煌) or elsewhere can be identified as specimens of sacred space. It is worth mentioning in passing that the paintings in some caves in Dunhuang reflect the cult of the book among the Uyghurs. They are connected with the Gandaryūhasütra, the final part of the Avatamsakasütra, in the case of the Mogao Cave B 464, while other inscriptions of this grotto refer in cartouches to the Suvarnaprabhāsasütra ${ }^{6}$ (a section on the ten bhümis). Peter Zieme has discovered a close connection between the paintings of this grotto and the texts accompanying them. ${ }^{7}$ In the case of this particular cave, artistic expression follows the patterns laid out by the basic texts.

As one would expect, the holy places of Buddhism in India are-as in other Buddhist traditions-highly significant in Uyghur Buddhism, and most of them are connected with the bodily presence of the Buddha; that is, in the form of relics or in traces left behind such as footprints, the mark of his shadow and so on. This 'grid's is the religious grounding for a transnational religion in the 'diasporic space' ${ }^{\text {' }}$ or — as it was put recently—in the Buddhist 'cosmopolis.' ${ }^{10}$

Takao Moriyasu, Die Geschichte des uigurischen Manichäismus an der Seidenstraße: Forschungen zu manichäischen Quellen und ihrem geschichtlichen Hintergrund (Wiesbaden: Harrassowitz, 2004), 1-30; Takao Moriyasu, "The West Uighur Kingdom and Tun-huang around the 1oth-11th Centuries," Berlin-Brandenburgische Akademie der Wissenschaften - Berichte und Abhandlungen 8 (2000): 342-344.

5 Kim Knott, "Spatial Theory and Method for the Study of Religion," Temenos 41.2 (2005a): 10, following de Certeau.

6 Peter Zieme, "Paul Pelliot, les études turques et quelques notes sur la grotte B 464 de Mogao," in Paul Pelliot: de l'histoire à la légende, ed. Jean-Pierre Drège and Michel Zink (Paris: Académie des Inscriptions et Belles Lettres, 2013), 426-430.

7 Zieme, "Paul Pelliot," 429.

8 This network was recently defined as a 'Kultlandschaft' in Hans-Ulrich Wiemer, "Kulträume: Einführende Bemerkungen," in Kulträume: Studien zum Verhältnis von Kult und Raum in alten Kulturen, ed. Hans-Ulrich Wiemer (Stuttgart: Franz Steiner, 2017), 9: "Kulträume können schließlich miteinander verknüpft sein, sei es, daß sie in eine Sequenz kultischer Handlungen, ein Kultprogramm, einbezogen sind, sei es, daß sie als Teil eines größeren Ganzen gedacht werden. Erfolgt diese Verknüpfung performativ, kann man von einer Kultlandschaft sprechen, die durch das Beziehungsnetz konstituiert wird, das zwischen mehreren Kulträumen besteht."

9 Knott, "Spatial Theory," 9.

10 Tansen Sen, "Yijing and the Buddhist Cosmopolis of the Seventh Century," in Texts and Transformations: Essays in Honor of the 75th Birthday of Victor H. Mair, ed. Haun Saussy (Amherst: Cambria Press, 2018), 345-368. 
Rich material is found mainly in translated works such as in the Old Uyghur version of the biography of the Buddhist pilgrim and eminent monk and translator Xuanzang (6oo/6o2-664, 玄娤). ${ }^{11}$ The translation can be roughly dated to the first half of the 11th century. In the fifth chapter, especially, places where the Buddha trod are mentioned, for instance, when the Tripitaka master sets out for Kauśāmbī to visit the Ghoṣilārāma Monastery. ${ }^{12}$ Concerning the termi-

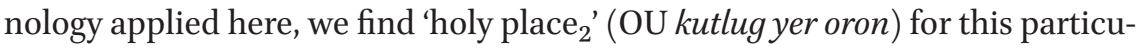
lar monastery. ${ }^{13}$ Xuanzang bowed here to the remains of the ladder by which the Buddha descended in Sāṃāśya while performing the devāvatāraṇa miracle. ${ }^{14}$ The learned masters of Nālandā try to persuade Xuanzang to stay in India by referring to the traces the Buddha left behind before he entered nirvanna. ${ }^{15}$ One Old Uyghur text admonishes the believers to revere holy places in India that were connected with Buddha's life. This Caityastotra is a part of the introductory portion of the Altun Yaruk Sudur, the Old Uyghur version of the Suvarnaprabhāsasūtra ${ }^{16}$ - the Tibetan version of which has survived as well. ${ }^{17}$ Obviously, as a block-printed edition shows, the work, which has no known exact parallel in any other Caityastotra text, was "also transmitted as a separate work among the Uigurs." ${ }^{18}$ It is a praise of the eight caityas. Another Uyghur text on caitya veneration was made available to the public by Peter Zieme in $2007 .{ }^{19}$ No parallel in any other language has come up so far and there are some peculiar details mentioned which are unique to the Old Uyghur text. Only two leaves have been identified which deal with the second and fourth caitya of the traditional set of eight; that is, respectively, the commemoration of the awakening and defeat of Māra at Uruvilvā and the Buddha's visit to his

11 The full title in Old Uyghur is bodis $(a) t(a) v$ taito samtso ačarinı yorıkn ukıtmak atl $(\iota) g$ tsi-en-čüen tegmä kavi nom bitig [Kāvya Text ${ }_{2}$ Named Ci-en-zhuan with the title "Biography of the Bodhisattva and Tripitaka Master of the Great Tang Dynasty"]. Siglinde Dietz, Mehmet Ölmez, and Klaus Röhrborn, Die alttürkische Xuanzang-Biographie v. Nach der Handschrift von Paris und St. Petersburg sowie nach dem Transkript von Annemarie v. Gabain ediert, übersetzt und kommentiert (Wiesbaden: Harrassowitz, 2015), 154-155 (lines 1320-1335).

13 Dietz, Ölmez, and Röhrborn, Xuanzang-Biographie V, 154 (line 1327).

14 Ibid., 155 (lines 1331-1335).

15 Ibid., 43 (lines 0079-0085).

16 Dieter Maue and Klaus Röhrborn, "Ein Caityastotra aus dem alttürkischen GoldglanzSūtra," Zeitschrift der Deutschen Morgenländischen Gesellschaft 129 (1979): 282-320.

Although it states in the colophon that the Old Uyghur translation by a certain Amoghaśrī (d.u.) is based on a Sanskrit original, it appears to be at least partly modeled after the Tibetan version. See Maue and Röhrborn, "Ein Caityastotra," 289. 
mother in the Trāyastrimiśa Heaven, starting in Sāṃkāśya. The title of the work is caiti (i.e. Skt. Caitya). In the case of both significant events, the notion of sacred space is combined with a detailed dating, which can be interpreted as a particular, auspicious moment. In an avadāna text interspersed with poetical parts in strophic alliteration, some epithets of the Jetavana Monastery (OU četavan sänräm $)^{20}$ are enumerated; one of which is that it is "an exquisite ${ }_{2}$ subhümi location" (OU üdrülmiš säčilmiš subum oronluk) ${ }^{21}$, which is to say, 'an auspicious place.' The Uyghurs apparently had a specific Indic terminology at their command to describe sacred space, while in this case, the term subhümi is uncommon in Sanskrit. The description of the conditions of Buddha's deeds in Śrāvastī, ruled by King Prasenajit, and of the position of samgha and laymen obviously serves as a model for the West Uyghur Kingdom (mid-gth c. to 13th c.) in this text.

In ryäkaranas it is possible not only to link persons of the past-often people associated in one way or another with different Buddhas-with high ranking Uyghur noble men and women but also to forge a symbolic connection between holy places in India and in the Uyghur realm, especially with Kočo. In one text edited by Masahiro Shōgaito, this is especially conspicuous. ${ }^{22}$ A diagnosis of the present situation is given, speaking of a time of degeneration, depravity and impurity, in which the Uyghur nobility tirelessly works to rebuild a thriving Buddhist community. They are even called the 'charisma of the realm of Kočo' (OU kočo ulušnuy kuțı kivl), ${ }^{23}$ a term reminiscent of the protective deities guarding the land of the Uyghurs. ${ }^{24}$ The alleviation of the woes of the present is supposed to finally lead the people to be reborn here on earth, when Maitreya will attain Buddhahood, in order to receive the prophecy for their own bodhi from him. In one Uyghur text, Maitreya's descent is located

20 Orthography normalised here.

21 Masahiro Shōgaito, "Drei zum Avalokiteśvara-sūtra passende Avadānas," in Der türkische Buddhismus in der japanischen Forschung, ed. Jens Peter Laut and Klaus Röhrborn (Wiesbaden: Harrassowitz, 1988), 90 (line 252).

22 Shōgaito, "Avalokiteśvara-sūtra," 94-98 (lines 300-343).

23 Ibid., 96 (line 317).

24 We know from a Manichaean text that the Uyghurs thought that the city of Kočo (Chin. Gaochang, 高昌) was guarded by twenty-two protective spirits. See M III, 40 (text no. 23, verso lines 6-7). In Buddhist texts, protective deities guarding the house or the palace of the king are mentioned several times (references in BT XXXVII, 501, commentary to lines 05294-05296). In the introductory chapter of the Maitrisimit, the protective spirit of the realm of Kočo is mentioned together with pan-Indian deities. See Jens P. Laut, "Gedanken zum alttürkischen Stabreim," in Splitter aus der Gegend von Turfan: Festschrift für Peter Zieme, ed. Mehmet Ölmez and Simone-Christiane Raschmann (Istanbul, Berlin: Ölmez, 2002), 134-135. 
precisely in a certain village near a certain city in China, ${ }^{25}$ while it is usually expected to occur in Ketumatī (present-day Varanasi in India).

\section{$2 \quad$ Terminological Observations}

When discussing sacred space in Uyghur Buddhism, some terminological observations might be useful. If we look at the Old Uyghur texts, three words come to mind when space is described as holy, symbolically charged or out of the ordinary. The first one is korıg or korıglıg, originally denoting an enclosed space which is imbued with a quality that can be described as 'taboo' in the wider sense of the term, not unlike the Latin sanctum. It survives in some modern Turkic languages. ${ }^{26}$ In Old Uyghur Buddhist texts, both words are only used with reference to tabooed women or girls, especially those living in the women's quarters of a palace. The connotation 'private property of chiefs' is present in Karakhanidic Turkic. The word is adopted in Mongolian too, where it can refer to any place bearing a taboo; for instance, the burial ground of the ruler ${ }^{27}$ or an 'inviolate grove'28. It is not altogether certain whether the word had this specific connotation in Old Turkic as well. As far as I can see, it is not present in Old Uyghur texts edited so far. While the usual word for 'protect' is küzädküzät- in Old Uyghur, occasionally korl-— the etymon of korıg — is applied. In

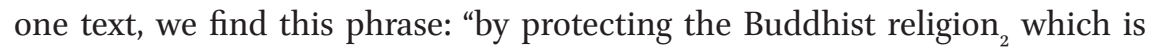
called 'good' from outside harm and dangers ${ }_{2}$. ${ }^{29}$ We can clearly detect a spatial

25 Annemarie von Gabain, "Ein uigurischer Maitreya-Text aus der Sammlung Tachibana (aus dem Nachlaß herausgegeben von Peter Zieme)," Berlin-Brandenburgische Akademie der Wissenschaften - Berichte und Abhandlungen 9 (2002): 233 (lines 082-087).

26 von Gabain, "Maitreya-Text," 233.

27 "To be sure, as Pelliot observed, a qoruq was not necessarily an actual tomb-site in the Mongol age; the term could refer to any forbidden precinct, and as Bartol'd observed, the term was not restricted to 'topography' in its application: the name of a deceased khan, which was not to be used or spoken for three generations, is spoken of as a qoruq, i. e., 'taboo,' by Rašìd ad-Dīn, and the term qorug či applied to the guardians of the royal tombsites was also used for guardians of the royal harem." Devin DeWeese, Islamization and Native Religion in the Golden Horde: Baba Tükles and Conversion to Islam in Historical and Epic Tradition (University Park, Pennsylvania: The Pennsylvania State University Press, 1994), 183. Note that qoruq is not found in classical Mongolian where we have qoriy, qoriya $(n)$ and qoruy-a.

28 DeWeese, Islamization and Native Religion, 183.

29 OU ädgü tetyük nomug šazinıg taštın sınarkı apakšal ada tudalartın korıyu, in ed. Zhang Tieshan and Peter Zieme, "A Further Fragment of Old Uigur Annals," Acta Orientalia Academiae Scientiarum Hungaricae 66.4 (2013): 401 (lines 50-51). 
model here. The good (i.e. Buddhism), being in the centre, is to be protected from evil coming from outside.

The second word, the adjective $\imath d o k$, 'holy,' can refer to a place-for instance, to the bodhimand $a^{30}$ or a caity $a^{31}$ — but also to persons as 'holy one(s),' thus operating as a noun. It may even denote deceased persons; for example, in the sentence "May our mother and father, the holy ones (i.e. the deceased ones) be reborn above in the Tușita (heaven)." ${ }^{32}$ Etymologically, the word is derived from the verb 'to send' (OT $\iota d$-), and according to the dictionary by Gerard Clauson, means "sent, i.e. dedicated, to God." ${ }^{33}$ Originally, according to Maḥmūd al-Kāšğarī's Dīwān Luḡät at-Turk [Compendium of the Turkic Dialects] (completed 1077), the word refers to an "animal which is set free [...]; its back is not loaded nor its udders milked nor its fleece shorn because of a vow incumbent on its owner." 34 Although this practice is not found in the Old Uyghur texts so far, it is still known among some modern Turkic speaking peoples as well as among the Mongols. ${ }^{35}$ The category of the sacred is thus connected with the notion of space (away from the deictic centre) and, originally—as is surmised - a rite of passage. ${ }^{36}$ The sacred belongs to the outside and is kept at bay from the social world. The title of the ruler of the West Uyghur Kingdom was ıdok kut (lit. Holy Charisma), a combination of two terms essential to the

30 Cf. the following quote from a poem: "at this holy ${ }_{2}$ bodhimanda" (OU adınčıg ıdok bo tavčolug oronta), quoted after BT XIII, 106 (text no. 15:5).

$31 \quad$ BT III, 71 (line 1017).

32 OU ögümüz kaๆımız ıdoklar üstün tužit tugzunl[ar]. See Peter Zieme, "Bolalım bäg yutuz - Ein buddhistisches Stabreimgedicht aus Toyok," in Şinasi Tekin'in anısına: Uygurlardan Osmanlıya [In Memory of Şinasi Tekin: From the Uyghurs to the Ottomans], ed. Günay Kut and Fatma Büyükkarcı Yılmaz (Istanbul: Simurg Kitapçıllk, 2005), 735 (IX).

33 Sir Gerard Clauson, An Etymological Dictionary of Pre-Thirteenth-Century Turkish (Oxford: Clarendon Press, 1972), 46a. The word is possibly etymologically connected with Mongolian iduyan ( udayan uduyan) 'shamaness.' See Juha Janhunen, "Siberian Shamanistic Terminology," in Traces of the Central Asian Culture in the North: Finnish-Soviet Joint Scientific Symposium Held in Hanasaari, Espoo 14-21 January 1985, ed. Ildikó Lehtinen (Helsinki: Suomalais-Ugrilainen Seura, 1986), 101.

34 Translation according to Clauson, Etymological Dictionary, 46b. Marcel Erdal has his reservations regarding this etymology of $\iota d o k$ : "We cannot, at present, exclude the possibility that Kāšgarin got this idea from the meaning of $\iota d m a$ yılkı, which he documents with the meaning 'an animal which is allowed to go free." See Marcel Erdal, Old Turkic Word Formation: A Functional Approach to the Lexicon, vol. 1 (Wiesbaden: Harrassowitz, 1991), 233.

35 See Elisabetta Chiodo, "The Horse White-as-Egg (öndegen čayan): A Study of the Custom of Consecrating Animals to Deities," Ural-Altaische Jahrbücher Neue Folge 11 (1992): 125151. In her article she compares Turkic and Mongolic materials.

36 Sacred space and 'boundary zones' are investigated in Veikko Anttonen, "Space, Body, and the Notion of Boundary: A Category-Theoretical Approach to Religion," Temenos 41.2 (2005): 185-201. 
study of concepts of the holy and the sacred among the Uyghurs. ${ }^{37}$ The ideas about kut - the third word to be examined briefly here - were still important after the conversion to Manichaeism and later to Buddhism. ${ }^{38}$ In Turkic, $k u t$ is a multifaceted term with a wide range of meanings; for example, 'royal charisma,' 'good fortune,' 'majesty,' 'salvation,' 'aim of salvation,' 'rank,' 'blessing,' 'grace,' 'merit,' 'protective spirit,' 'soul,' 'vow,' 'element,' 'quality,' and so forth. Persons and places can be the seat of kut-imagined as a kind of substance and coming from above ${ }^{39}$ - which makes them special in a religious sense. In Uyghur Buddhism, kut became conflated with the concept of punya (OU buyan). The latter not only bears the usual meaning of 'merit' but also 'good fortune, 'grace,' 'majesty,' and so on when used in synonym compounds with kut. Just like the amount of kut in heaven, the store of punya which can be dedicated to others is sometimes imagined as residing in heaven above. ${ }^{40}$

I would argue that in the royal title, the horizontal aspect of the holy (OU $\iota d o k$ ) is combined with the vertical aspect (OU kut). ${ }^{41} \mathrm{~A}$ striking 'survival' of the pre-Buddhist and pre-Manichaean conception of kut is found in two Buddhist texts edited by Kōgi Kudara and Juten Oda respectively. Both are translations from Chinese. In the first one, a Uyghur version of the *Taishan jing 太山經 [sütra of Mount Tai], ${ }^{42}$ we find: "his lifespan will be long, his good fortune (OU kut) thick"43 (OU özi uzun kutı kalın bolgay). And in the second text, the Säkiz Yükmäk, a translation from the Bayang jing 八陽經 [sūtra of the Eight Principles]:44 "his lifespan ${ }_{2}$ will be long, his good fortune (OU kut) will be thick"45

37 On this title, see Reşid Rahmeti Arat, "Der Herrschertitel Iduq-qut," Ural-Altaische Jahrbücher 35 (1964): 150-157. Róna-Tas rightly stated that there must have been a difference between the two constituents of the term ıdok kut. See András Róna-Tas, "Materialien zur alten Religion der Türken," in Synkretismus in den Religionen Zentralasiens: Ergebnisse eines Kolloquiums vom 24.5. bis 26.5.1983 in St. Augustin bei Bonn, ed. Walther Heissig and Hans-Joachim Klimkeit (Wiesbaden: Harrassowitz, 1987), 39.

38 On the Turks' ideas about kut, see Róna-Tas, "Materialien," 40.

39 Ibid., 41.

40 BT xxxvin, 168 (text Gb27).

$41 \quad$ Róna-Tas, "Materialien," 42, says that the ruler is the kut itself.

42 The Chinese title is reconstructed after the OU title taišanke.

43 Kudara Kōgi, "Kanbun 'Taizankyō' to uiguruyaku Tayšanki. Torufan chihō no amida butsu kankei no gikyō 漢文太山経とウイグル訳 Tayšanki. 一トルファン地方の阿弥陀佛 関係の偽経 [Chinese Taishan jing and Uyghur Tayšanki-Unknown Apocrypha on Amida Buddha in the Turfan Area]," Ryūkoku daigaku ronshū 龍谷大學論集 [Journal of Ryūkoku University] 463 (2004): 4 (lines 15-16).

44 The full title of this text is usually given as Foshuo tiandi bayang shenzhou jing 佛說天地 八陽神呪經 [ mantra-sūtra of the Eight Principles of Heaven and Earth as Spoken by the Buddha].

45 BT XxXIII, 230 [437, Ib] (I deviate from Oda's translation). The Chinese parallel deviates here. Cf. Oda, A Study, 231. 
(OU öziyašı uzun bolur kutı kalın bolur). We can compare the small Karabalgasun Inscription written a few decades after the conversion to Manichaeism, where the kut of the ruler is said to have become 'thin' (OT yuyka) in the blue heaven. ${ }^{46}$ This idea is certainly pre-Manichaean. In another translated text, the ninth chapter of the Biography of Xuanzang, kut is said to have settled down (i.e. from above) on the Anfumen (安福門) street, originally the city gate, in Chang'an (長安, modern Xi'an 西安). ${ }^{47}$ Thus the ideas about kut form a preBuddhist and pre-Manichaean layer within Uyghur culture. As in the instance in the Biography of Xuanzang quoted at the beginning of the paper, a place can be imbibed with kut. The term 'the holy realm of Kočo' (OU kutlug kočo uluš) can be found within the texts. ${ }^{48}$ The winter capital of the Uyghurs, Kočo, seems to be the focus of the whole realm, or even identical with it. ${ }^{49}$ The holiness of a whole city is a concept found in another context. In a fragment of a text which is probably part of a historical elaboration, there is a description of how a ruined city called ordo uluš — probably to be understood as 'residence'—-was

46 Quoted after Róna-Tas, "Materialien," 41, where it is stated correctly that the inscription reflects the old ideas about kut even though it was written after the conversion to Manichaeism. As the inscription belongs to the East Uyghur Khaganate (ca. 744-840), it has to be surmised that the conception of kut was similar to the belief expressed in the Old Turkic inscriptions of the Orkhon Valley.

47 Hakan Aydemir, Die alttürkische Xuanzang-Biographie IX: Nach der Handschrift von Paris, Peking und St. Petersburg sowie nach dem Transkript von Annemarie v. Gabain ediert, übersetzt und kommentiert, vol. 1 (Wiesbaden: Harrassowitz, 2013), 108, (line 582). Cf. also ibid., 110 (line 599). Further attestations in the 7 th chapter are discussed in the commentary to the first passage in Aydemir, Xuanzang-Biographie IX, vol. 2, 321, where it is rightly stated that the translator of the ninth chapter misunderstood the syntax because kut ornanmiš ('[where] the divine fortune has descended') should refer to the gate and not the street. Kirill Solonin points out to me that in both cases the Old Uyghur translation differs from the Chinese original because instead of an equivalent for kut, the emperor is mentioned (personal communication).

48 Takao Moriyasu, "Uighur Buddhist Stake Inscriptions from Turfan," in De Dunhuang à Istanbul: Hommage à James Russell Hamilton, ed. Louis Bazin and Peter Zieme (Turnhout: Brepols, 2001), 186 (line 04); Peter Zieme, "Remarks on Old Turkish Topography," in Languages and Scripts of Central Asia, ed. Shirin Akiner and Nicholas Sims-Williams (London: School of Oriental and African Studies, 1997), 50 (line 4). BT xxxviII, 235 (text Jeo5); Laut, "Gedanken," 134 (line 29, a colophon to the introductory part of the Maitrisimit; here: OU kutlug kočo uluš kutı "the protective spirit of the holy realm of Kočo"). See the title kutlug kočo ulušlug kanpo bišayčup ırpal bahšı "the abbot (Tib. mkhan po) Guru Byan chub dpal who belongs to the holy realm of Kočo" BT VII, 76 (text O 17-18).

49 Jens P. Laut and Peter Zieme, "Ein zweisprachiger Lobpreis auf den Bäg von Kočo und seine Gemahlin," in Buddhistische Erzählliteratur und Hagiographie in türkischer Überlieferung, ed. Jens P. Laut and Klaus Röhrborn (Wiesbaden: Harrassowitz, 1990), 23 (line 36): kočo uluštakı bodun bokun kuvrag[ı] "the host of the people in the realm of Kočo (Gaochang)." 
rebuilt. In one line it is called 'divine city' (OU $t(\ddot{a}) \eta r i b a l ı k) .{ }^{50}$ There is also a reference to 'heavenly winter quarters' (OU t(ä) yridäm kıšlıklar).${ }^{51}$ The identity of this ruined city is not altogether certain.

After the Uyghurs had to leave their original homeland in Mongolia and settled along the northern rim of the Tarim Basin during the middle of the gth century, they had to face new environmental and cultural conditions. Although some Uyghurs were already living along the northern rim of the Tarim Basin before the demise of the East Uyghur Kaganate (ca. 744-840) in Mongolia, the major part of the Uyghur populace entered the world of the small oases only in the 9 th century. We can safely assume that their perception of space underwent important changes at that time. As Michael C. Brose points out:

By the eleventh century the Uyghurs had themselves become Tarim Basin indigenes whose kingdom controlled the area, and whose identity was shaped by their ancient imperial history and their immediate sociocultural context. ${ }^{52}$

Occasionally the Uyghurs reflected on their surroundings in their writings. I would like to mention briefly a text in strophical alliteration known as the 'Jade Empress,' first edited by Kudara in $2001^{53}$ and re-edited by Abdurishid Yakup in 2014. ${ }^{54}$ Additional remarks were made by Peter Zieme in two articles

$50 \quad$ Peter Zieme, "Ordo Uluš, Solmı and Bešbalık," Acta Orientalia Academiae Scientiarum Hungaricae 62.3 (2009): 257 (line 6).

$51 \quad$ Zieme, "Ordo Uluš," 257 (line 8).

52 Michael C. Brose, "People in the Middle: Uyghurs in the Northwest Frontier Zone," in Battlefronts Real and Imagined: War, Border, and Identity in the Chinese Middle Period, ed. Don J. Wyatt (New York: Palgrave Macmillan, 2008), 255.

53 Kudara, Kōgi, "Saiiki shogo dankan shū (19.20) chōsa chūkan hōkoku 西域諸語断簡 集 $(19 \cdot 20)$ 調查中間報告 [Collection of Fragments in Different Languages from Central Asia (19.20) Midterm Research Report]," Tōkyō daigaku shozō bukkyō kankei kichōsho ten-tenji shiryō mokuroku 東京大学所蔵仏教関係貴重書展一展示資料 目録一 [Precious Buddhist Manuscripts in the University of Tōkyō Library-Catalogue of the Materials on Display] (Tokyo: University of Tōkyō Library, 2001), 20-24.

54 Abdurishid Yakup, "Dongjing daxue fushu tushuguan cang huihu wen < feicui gongzhu zan> yishi 东京大学附属图书馆藏回鹘文〈翡斈公公赞〉译释 [Translation of the Uyghur 'Praise on the Jade Princess' in the Library of the University of Tokyo]," in Neilu Ouya lishiyuyan lunji一Xu Wenkanxiansheng guxijinian 内陆欧亚历史语言论集徐文 堪先生古稀纪念 [Studies on the History and Languages of Inner Eurasia一Festschrift 
published on academia.edu in the summer of 2015,55 in which he introduced newly identified fragments and also some important new readings. The spirit named the Jade Empress (OU kaš hatun) is characterised as a descendant of the Nāga Vāsuki who has her residence "in the valley of Karakočo" (OU kara kočo özäkintä) "with its banks rich in jade" (OU kašlıg kıdıglıg). ${ }^{56}$ It is explicitly stated in the text that the Uyghurs call her kaš hatun, the Jade Empress. ${ }^{57} \mathrm{Al}-$ though one text mentions a nun called kaš hatun from Toyok, ${ }^{58}$ the legendary creature in the poem simply cannot be a human being. The references to mythology are too explicit. The poem reflects the Uyghurs' perception of their own landscape with kaš hatun as a beneficent entity who provides water in an arid region. The newly identified text ${ }^{59}$ seems to point to a use of the poem in the context of rain magic.

\section{$4 \quad$ A Uyghur Approach to Sacred Space?}

Taking the imagery of the poem of the Jade Empress as a starting point, one is tempted to ask whether there is a special Uyghur way of conceiving sacred space. In order to give an answer to this question, one would be well advised to investigate those sources which are most likely to be original Uyghur compositions; that is, poems, colophons, inscriptions and letters. The literary genre can be somewhat blurred at times because colophons or inscriptions can be written in strophic alliteration, the typical feature of Altaic poetry. ${ }^{60}$ There is one particular poem in sixteen lines with a kind of chorus after each stanza, which praises a quiet and secluded monastery and the nature surrounding it. ${ }^{61}$ The landscape and vegetation is typical of the arid and mountainous regions of the Tarim Basin. A river is always of vital importance for the cave monasteries in

on Occasion of the 7oth Birthday of Professor Xu Wenkan], ed. Xu Quansheng 许全胜 and Liu Zhen 刘震 (Lanzhou: Lanzhou daxue chubanshe, 2014), 148-161.

Peter Zieme, “Notizen zur 'Jadeherrin'," June, 2015, accessed August 24, 2018. <https:// www.academia.edu/12823748/Notizen_zur_Jadeherrin_>; "Weitere Notizen zur 'Jadeherrin'," July, 2015, accessed August 24, 2018>. <https://www.academia.edu/13303452/ Weitere_Notizen_zur_Jadeherrin_>.

56 Yakup, "Feicui gongzhu zan," 154.

57 Yakup, "Feicui gongzhu zan," 154.

58 Zieme, "Notizen," 3.

59 BT XIII, 138-139 (text no. 27; newly identified in Zieme, "Weitere Notizen").

6o And there are Uyghur versifications of texts in donor languages such as Chinese or Sanskrit.

61 Peter Zieme, Die Stabreimtexte der Uiguren von Turfan und Dunhuang: Studien zur alttürkischen Dichtung (Budapest: Akadémiai Kiadó, 1991), 117. 
this area while caves are also an essential part of the pre-Buddhist religion of the ancient Turks. ${ }^{62}$ Running water as well as dense forests and foaming lakes add to the picture represented in the Buddhist poem, too. Only in such a place would one be able to control one's senses and enjoy in complete solitude the pleasure of the dharma, as the text states. ${ }^{63}$ It is remarkable that the author depicts the landscape as something enjoyable, with an inherent aesthetic quality, and a complement to the benefits of meditation.

But not only monastic life is depicted in the religious texts. In one composition traditionally called the Harvest Blessing, ${ }^{64}$ there is a very positive description of agricultural activities. ${ }^{65}$ The backdrop of this text is Buddhist, but with a very specific local content. There is a second Harvest Blessing 66 in which the god Dhanyadeva is given ritual oblations. This deity is mentioned in the first Harvest Blessing too. In the Maitrisimit we find the native Uyghur term tarig täyri, God of Cereals, ${ }^{67}$ and it is highly likely that this name refers to the same deity. In the second Harvest Blessing, offerings to Dhanyadeva are supposed to please him so that he procures rich amounts of grain. Both texts display a poetical structure in strophic alliteration. Parts of both texts are not well understood; some terms have been interpreted only in a preliminary way. It is conceivable that both blessings were meant to be recited to accompany agricultural rituals. In a region with very little rain, where cultivation is usually only possible with elaborate irrigation, a ritual focus on the soil is quite understandable. On the other hand, the high esteem in which agricultural activities are held in these texts is somewhat surprising as tilling the soil is usually viewed negatively in a Buddhist context. One Uyghur example explicitly describes several of these activities as "harming ${ }_{2}$ the true ${ }_{2}$ inner self of all the Buddhas in the three worlds." 68

62 On caves as a seat of 'numinous powers,' see Rolf Gehlen, "Raum," in Handbuch religionswissenschaftlicher Grundbegriffe. IV: Kultbild - Rolle, ed. Hubert Cancik, Burkhard Gladigow, and Karl-Heinz Kohl (Stuttgart, Berlin, Köln: W. Kohlhammer, 1998), 377-398.

63 Zieme, Stabreimtexte, 117 (line 12). This is a re-edition of Reşid Rahmeti Arat, Eski Türkşiiri [Old Turkic poetry] (Ankara: Türk Tarih Kurumu Basımevi, 1991), 66-67 (text 8).

64 Peter Zieme, "Ein uigurischer Erntesegen," Altorientalische Forschungen 3 (1975): 109-143.

65 Zieme, "Erntesegen," 113-114 (lines 22-59).

66 Ádám Molnár and Peter Zieme, "Ein weiterer uigurischer Erntesegen," Altorientalische Forschungen 16.1 (1989): 140-152.

67 Version from Hami, chapter XXVI, leaf 8 (verso 11-12). See Geng Shimin, Jens P. Laut, and Georges-Jean Pinault, "Neue Ergebnisse der Maitrisimit-Forschung (II): Struktur und Inhalt des 26. Kapitels," Studies on the Inner Asian Languages 19 (2004): 6o.

68 OU üčyer suvdakı tüzü burhannıฤ kertü köni özläri buzuglı artat( $\iota) g l ı ̈$ ärr, in manuscript Mainz 774, lines 10-12 (verso), quoted in Peter Zieme, "Uigurische Steuerbefreiungsurkunden für buddhistische Klöster," Altorientalische Forschungen 8 (1981): 242 (note 46). 
If we leave the rather clearly defined realm of physical space, we may proceed to socially and symbolically constructed space. In several texts the land of the Uyghurs is mentioned. It can be imagined as a kind of holy land or as lying in the centre of civilisation. The Uyghur ruler is addressed in one poem as "oh our ruler, who was born in the centre (OU orta törümiš hanım( $\iota) z-a) . "{ }^{69}$ One poem speaks of the rewards for concentrating one's mind on the Buddhas of the ten directions, the first of which is that "one is born ${ }_{2}$ in the Uyghur land, the centre realm (OU uygur elilig orton ulušta tugup b(ä)lgürüp)."70 Further on, a rebirth in the Tușita Heaven is mentioned. ${ }^{71}$ Even in modern scholarship the Uyghurs were characterised as 'people of the middle. ${ }^{72}$ This is the relational aspect of the land of the Uyghurs. Periphery is imagined here as centre, a fact well known in spatial theory. The realm is threatened by enemies and other dangers. This is stated in the so-called Memorandum, a text of mixed prose and verse depicting the early phase of the West Uyghur Kingdom, which was committed to writing in the 13th or 14th century. Here, we find the interesting statement, "The holiest of realms is the realm of the On Uygur."73 The conception of their homeland is very likely to be an essential factor in the construction of Uyghur identity. In line forty of this text, there is reference to the old sacred centre of the Turkic peoples in the region of Ötükän. Land and ruler are seen as complementary in this text. The place name Ötükän or Ötịkän is attested in other texts as well. ${ }^{74}$ The place name Kičig Öțikän (Small Ötükän) found in one poetic text ${ }^{75}$ was probably relocated in the vicinity of Beš Balık - the summer capital of the Uyghurs - to remember the old sacred centre and to be in closer contact with a place imbibed with charisma. Notice that despite the mixed population of the Tarim Basin, what matters is that the land belongs to the Uyghurs in a Uyghur perspective. Buddhas, bodhisattvas and protective deities can be invoked to help secure the well-being of the land and its inhabitants. One example is a

\footnotetext{
$69 \quad$ BT XIII, 154 (text no. 39:9, 13).

70 Ibid. (text no. 55:4).

71 Ibid., 183 (text no. $55: 8$ ).

72 Brose, "People in the Middle."

73 Tieshan Zhang and Peter Zieme, "A Memorandum About the King of the On Uygur and his Realm," Acta Orientalia Academiae Scientiarum Hungaricae 64.2 (2011): 142 (line 36; OU eltä ıdokı on uygur eli ök ärmiš).

74 For references, see Peter Zieme, “Toyın körklüg': An Old Uigur Buddha Poem," Studies on the Inner Asian Languages 28 (2013): 22-23. The place name is also attested in Manichaean Sogdian. See Nicholas Sims-Williams and Desmond Durkin-Meisterernst, Dictionary of Manichaean Sogdian and Bactrian (Turnhout: Brepols, 2012), 38a.

Peter Zieme, "Toyın körklüg," 15 (line 5).
} 
praise of Maitreya recently edited by Yukiyo Kasai ${ }^{76}$ and re-examined shortly afterwards by Peter Zieme. ${ }^{77}$ In this highly difficult poem, which displays a peculiar imagery, Maitreya is asked to eradicate ailments and sufferings of the Uyghur people in the realm of Kočo.

There is one poem found in Yarkhoto which is a praise of the Uyghur realm. ${ }^{78}$ Coming back to the Memorandum, the term Ten Uyghurs (OU on uygur) is of importance. It appears in the Maitrisimit as "the praised realm of the Ten Uyghurs." ${ }^{79}$ In other texts, we even find a fictive Sanskrit term, daśahaihura 'Ten Uyghurs,' 80 and even daśahaihuramaṇdal (as a term written in Brāhmī script which is the designation of the realm of the Ten Uyghurs). ${ }^{81}$ We do not know exactly to what extent the tribal organisation was still effective in shaping social life in the West Uyghur Kingdom, but it most probably was still meaningful even after the Uyghurs became sedentary in the Tarim Basin, not only on a symbolical level. By using an Indian term, daśahaihura, the prestige of the Sanskrit tradition is transferred to the Uyghur realm in Central Asia. The "blessed and holy land of the Ten Uyghurs" is mentioned in a Manichaean hymn as well. ${ }^{82}$ The notion of centrality ${ }^{83}$ is evoked in a wall inscription by the two Uyghur monks Dharmaśri (d.u.) and Taypodu (d.u.), which bears the title sukavadi ulušnuy okıtıııı [Invocation of the Sukhāvatī Land]. It is one of several inscriptions on a wall painting with scenes from hells:

76 BT XXXVIII, 140-143.

77 Peter Zieme, "Altuigurischer Lobpreis auf Maitreya in Versen, die in der Anrufung, die Nöte des Uigurischen Reichs zu lindern, kulminieren,” April, 2017, accessed August 24, 2018. <https://www.academia.edu/32289782/Altuigurischer_Lobpreis_auf_Maitreya_in_ Versen_die_in_der_Anrufung_die_Nöte_des_Uigurischen_Reichs_zu_lindern,_kulmi nieren>.

78 BT XIII, 154-155 (text no. 39).

79 Geng Shimin and Hans-Joachim Klimkeit, Das Zusammentreffen mit Maitreya. Die ersten fünf Kapitel der Hami-Version der Maitrisimit, in Zusammenarbeit mit Helmut Eimer und Jens Peter Laut herausgegeben, übersetzt und kommentiert, vol. 1 (Wiesbaden: Harrassowitz, 1988), 12 (lines 23-24). Similarly, in a colophon in alliterative verse from the Saint Petersburg collection quoted in Zieme, "The West Uyghur Kingdom," 8 (SI 4bKr 6 recto 9-11): "One who keeps and protects without spoiling anything the pure and holy dharma and sâsana (of the Buddha) and the blessed realm and country of the On Uygur forever, for countless eons" (OU arıg ıdok nomın šazının/alkatmıš on uygur elin ulušın/apamulug üd suratılıg tuškatägi/artadmatın küyü küzädü tuttačı).

8o BT XXXVIII 136 (line Ea13). Also, in the poem in Uyghur script, we find haihurlar for 'Uyghurs.' See Zieme, “Notizen,” 3 (IIId).

81 Zieme, "Old Turkish Topography," 47. Note the elision of the final -a of the Sanskrit term which corresponds with the usual spelling of mandal mantal in Uyghur script.

82 TT IX 18 (line 9o; OU alkatmıš ıdok [o]n uygur eli).

83 On the image of the centre in the history of religions see Gehlen, "Raum," 394-395. 
look, in this cella (of the) monastery ${ }^{84}$

which is nothing less than the pillar of the land of the Ten Uyghurs

look in this excellent monastery gorge. ${ }^{85}$

In spatial theory, the human body is identified as "the source of 'space." 86 It is seen as the key to concepts of orientation. In some Uyghur Buddhist texts translated from other languages, we can detect this idea as well. A telling usage of two metaphors is found in chapter 11 of the work Maitrisimit. The moment of conception in the case of the Bodhisattva Maitreya is described as first leaving the Tusita palace and then "entering the darkness of the womb of queen Brahmāvatî." ${ }^{87}$ In the same chapter, queen Brahmāvatī approaches a rose-apple tree to give birth to Maitreya. At this very same spot grew the aśoka tree under which Śākyamuni was born. And then a second metaphor is found: "At this very same sacred place ${ }_{2}$ did the god of gods, Buddha Kāśyapa, Buddha Kanakamuni, and Buddha Krakucchanda leave the palace of (their) mothers' womb." ${ }^{88}$ The presence of the bodhisattva transfigures his mother's womb, otherwise perceived as a place of darkness and despair, into a receptacle of the holy. ${ }^{89}$ In the 26 th chapter of the same text there is a damaged passage which contains a description of the cosmological Buddha. In this case it is King Simha

\footnotetext{
84 The term manistan usually but not exclusively refers to a Manichaean monastery.

85 BT XIII (text no. 59:2-5):

una bo manistan özäntä

on uygur el ulušnuy

ugrayu soka basrokı

una bo ništa aryadan kısılta

86 Knott, "Spatial Theory," 4, 22-23; Gehlen, "Raum," 393: "Erklärbar ist diese Dominanz des Zentrums aus der Stellung des Menschen im Raum mit dem eigenen Körper als Koordinatennullpunkt."

87 OU br(a)hmavati hatunnuy karanlag tünärigintä olurur. Chapter 11, folio 3, verso 23-24. Geng Shimin, Hans-Joachim Klimkeit, and Jens P. Laut, "Das Erscheinen des Bodhisattva'. Das 11. Kapitel der Hami-Handschrift der Maitrisimit," Altorientalische Forschungen 15.2 (1988): 323. For a damaged parallel from Sengim, see now Michaël Peyrot and Ablet Semet, "A Comparative Study of the Beginning of the 11th Act of the Tocharian A Maitreyasamitināțaka and the Old Uyghur Maitrisimit," Acta Orientalia Academiae Scientiarum Hungaricae 69.4 (2016): 361 (lines o99-101).

88 Chapter 11, folio 8, verso 16-20. Geng, Klimkeit, and Laut, eds., "Erscheinen des Bodhisattva," 328-329 (OU ol ok kutlugyer oronta t(ä)yrit(ä)yrisi kašip burhan kanakamuni burhan kr(a)kašunde burhan [ö]g karınlag vimanıntın ünä y(a)rlıkadılar).

89 Ibid., 318.
} 
observing the four continents and other auspicious marks such as bejewelled kutägaras on the back and haunches of Maitreya. ${ }^{90}$ It is possible that passages such as this one and lists of the thirty-two lakșanas were used to visualise in meditative practices. Note that the Maitrisimit is one of the earliest Old Uyghur Buddhist texts. It was translated from Tocharian A into Old Uyghur probably in the gth century. After the classicial period in which translations from Chinese prevail, a new phase in Uyghur Buddhism began with the advent of Tibetan Buddhism in the late 13th century. The need for translations from Tibetan arose and new rituals and their accompanying mandalas and texts began to spread. The appropriation of Tibetan Tantric literature was seemingly rather selective, to judge from the texts identified so far. ${ }^{91}$ In a Cakrasamvvarasādhana translated from Tibetan by Punyaśri (d.u.) in the 14th century, there is an enumeration of the twenty-four spots of the body where the viras and yoginis reside. ${ }^{92}$ They correspond to the twenty-four outer places, such as Pulliramalaya, Jālandhara, Oḍḍiyāna, Arbuta, Godāvarī and so on. Thus, the body is envisaged as sacred space, with visualisation as a kind of inner pilgrimage.

\section{Concluding Remarks}

Through a philological examination of the complex issue of sacred space in Uyghur Buddhism, it has become clear that concepts developed in other Buddhist traditions of the area are adapted and reformulated, whereas others are connected with the Uyghurs' self-perception. They reflect how the Uyghurs positioned themselves within the Buddhist community and how they established their identity. In this respect, we can detect an intersection with the topic of 'legitimation,' which is discussed with reference to Uyghur Buddhism by Yukiyo Kasai in this volume. It is fortunate that Uyghur poetry has received a lot of attention from scholarship. Without our knowledge of poems, inscriptions and other original compositions, the Uyghurs' take on sacred space would look exceedingly derivative. Although references to the topic are more often than not rather sketchy, they nevertheless contain important information that provides direct insight into Buddhist life in the Tarim Basin on an individual level, aside from authoritative texts.

\footnotetext{
$90 \quad$ See the short note by Jens P. Laut, "Noch einmal zum 26. Kapitel der Maitrisimit," Studies on the Inner Asian Languages 21 (2006): 183-184.

91 The most substantial contribution to the study of Tantric texts in recent years, comprising several new identifications, is BT XXXvI.

92

BT VII, 32-34 (text A, lines 31-84).
} 